Konservasi Hayati, 17 (2): 63-68, Oktober (2021)

https://ejournal.unib.ac.id/index.php/hayati/

p-ISSN: 0216-9487

email:konservasihayati@unib.ac.id

e-ISSN: 2722-1113

\title{
KEANEKARAGAMAN JAMUR PATOGEN DAN GEJALA YANG DITIMBULKAN PADA TANAMAN CABAI MERAH (Capsicum annuum L.) DI DATARAN RENDAH
}

\author{
Nur Wakhidah $^{{ }^{1}}{ }$, Kasrina ${ }^{1 *}$, Hendri Bustamam ${ }^{2}$ \\ ${ }^{1}$ Program Studi Pendidikan Biologi, Jurusan Pendidikan Matematika dan Ilmu Pengetahuan \\ Alam Fakultas Keguruan dan Ilmu Pendidikan Universitas Bengkulu \\ ${ }^{2}$ Program Studi Proteksi Tanaman, Jurusan Perlindungan Tanaman Fakultas Pertanian \\ Universitas Bengkulu \\ *corresponding author : nurwakhidah66@gmail.com; kasrina@unib.ac.id
}

\begin{abstract}
Problems in cultivating red chili (Capsicum annuum L.) are an obstacle for farmers to obtain good yields. One of these problems is disease caused by pathogenic fungi. The exploratory method used in this study, namely by exploring red chili with symptoms of the disease to be taken as a sample. Plants with symptoms of the disease are then taken to the laboratory for isolation and identification of pathogenic fungi. From the results of this study obtained five types of pathogenic fungi in red chili. The pathogenic fungi found in this study were Fusarium sp., Curvularia sp., Colletotrichum sp., Phytophtora sp., and Cercospora sp. and the diseases found were Fusarium wilt, fruit brown spot, Anthracnose, Phytophthora leaf rot, and Cercospora spot.
\end{abstract}

Keywords: Lowlands, pathogenic fungi, Red chilies (Capsicum annuum L)

\begin{abstract}
ABSTRAK
Permasalahan dalam membudidayakan cabai merah (Capsicum annuum L.) menjadi hambatan bagi petani untuk menghasilkan buah yang baik. Salah satu permasalahan tersebut adalah penyakit yang disebabkan oleh jamur patogen. Metode eksplorasi digunakan dalam penelitian ini, yakni dengan mengeksplorasi cabai merah bergejala penyakit untuk diambil sebagai sampel. Tanaman yang bergejala penyakit kemudian dibawa ke laboratorium untuk dilakukan isolasi dan identifikasi jamur patogen. Dari hasil penelitian ini diperoleh lima jenis jamur patogen pada cabai merah. Jamur patogen yang ditemukan dalam penelitian ini adalah Fusarium sp., Curvularia sp., Colletotrichum sp., Phytophtora sp., dan Cercospora sp. dan penyakit yang ditemukan adalah Layu Fusarium, Bercak cokelat buah, Antraknosa, Busuk daun Phytophthora, dan Bercak Cercospora.
\end{abstract}

Kata kunci: Cabai merah (Capsicum annuum L.), Dataran rendah, Jamur patogen

\section{PENDAHULUAN}

Cabai merah (Capsicum annuum L.) termasuk kedalam kelompok tanaman holtikultura yang sangat umum dikenal dan diminati oleh berbagai kalangan masyarakat karena rasa buahnya yang pedas. Rasa buah yang pedas menjadi ciri khas tanaman ini karena terdapat kandungan capsaicin di dalamnya (Subagyono, 2010). Harga jual buah cabai merah terbilang cukup tinggi karena banyaknya permintaan buah cabai merah oleh konsumen.

Peningkatan jumlah penduduk setiap tahun menyebabkan kebutuhan cabai merah juga meningkat. Sehingga untuk memenuhi kebutuhan cabai merah, masyarakat membudidayakan cabai merah di pekarangan rumah 
ataupun di perkebunan. Cabai merah dapat dibudidayakan di dataran rendah hingga dataran tinggi dengan ketinggian $1.300 \mathrm{~m}$ dpl. Iklim ideal yang dibutuhkan tanaman ini untuk tumbuh dengan baik berada pada temperatur 25-30 ${ }^{\circ} \mathrm{C}$ (Harpenas \& Dermawan, 2010).

Kualitas buah yang baik dan jumlah buah yang banyak merupakan harapan bagi seluruh petani pada masa panen. Namun, beberapa faktor seperti kebanjiran, kekeringan, hama dan penyakit menjadi sebuah permasalahan yang sering ditemui dalam pembudidayaan cabai merah. Duriat et. al. (2007), menyatakan bahwa "antraknosa, layu Fusarium, bercak daun Cercospora, busuk daun Phytophtora, busuk buah, rebah batang, dan layu bakteri merupakan berbagai penyakit yang menyebabkan pertumbuhan tanaman cabai merah terhambat”. Penyebab penyakit tersebut didominasi oleh jamur patogen.

Jamur patogen yang menyebabkan penyakit pada cabai merah beragam jenisnya. Tanjung etal., (2018), menyatakan dalam penelitiannya diperoleh empat jenis jamur patogen pada tanaman cabai merah. Diantaranya Cercospora capsici, Phytophthora sp. Colletotrichum capsici dan Oidium sp.

Tujuan penelitian ini adalah untuk mengisolasi jamur patogen dari cabai merah berpenyakit, mengidentifikasi jenis jamur patogen, dan mendeskripsikan jamur patogen Kelurahan Padang Serai, Kota Bengkulu dan Desa Pekik Nyaring, Kabupaten Bengkulu Tengah.

\section{METODE}

Metode yang digunakan dalam penelitian ini adalah metode eksplorasi. Sampel diambil dengan melakukan eksplorasi tanaman cabai merah bergejala penyakit pada kebun cabai di dataran rendah wilayah Kelurahan Padang Serai Kota Bengkulu dan Desa Pekik Nyaring Kabupaten Bengkulu Tengah. Sampel yang diambil berupa bagian tanaman (daun, batang, dan buah) yang bergejala penyakit. Selanjutnya dilakukan tahapan identifikasi jenis jamur patogen terhadap sampel yang diperoleh tesebut di laboratorium Proteksi Tanaman Fakultas Pertanian Universitas Bengkulu.
Tahapan yang dilakukan sebelum mengidentifikasi jenis jamur patogen adalah dilakukan isolasi patogen dari jaringan tanaman yang bergejala penyakit. Adapun tahapan isolasi diawali dengan membuat beberapa potongan segi empat yang mengandung bagian yang sakit dan yang sehat berukuran 5-10 mm. Selanjutnya potongan tersebut disterilkan dari mikroba udara dengan direndam kedalam alkohol 70\% selama 15-30 detik. Kemudian potongan tersebut dibersihkan sisa alkoholnya dengan menggunakan akuades, lalu dikeringkan dengan tissue. Setelah potongan tersebut kering, kemudian diletakkan di atas medium Potato Dextrose Agar (PDA), kemudian diinkubasi selama 5-7 hari pada suhu ruangan hingga tumbuh jamur (Agrios, 1997).

Setelah tumbuh jamur, dilakukan pemurnian, yakni jamur patogen yang tumbuh dari isolasi dibiakkan kedalam media Potato Dextrose Agar (PDA) yang baru. Koloni murni jamur patogen yang tumbuh diamati karakteristiknya secara makroskopis dan mikroskipis untuk dijadikan dasar dalam mengidentifikasi jenis jamur tersebut. Secara makroskopis, diamati karakteristik koloni murni jamur patogen. Karakteristik yang diamati adalah warna, bentuk, simetris/tidak simetris, dan arah pertumbuhan koloni. Sedangkan karakteristik mikroskopis yang diamati adalah bagaimana bentuk, warna, bersekat/tidak bersekat spora atau konidia dan hifanya.

Identifikasi jamur patogen dilakukan dengan mengacu pada buku "Fitopatologi Ilmu Penyakit Tumbuhan” (Sastrahidayat, 2011), "Imperfect Fungi" (Barnet, 1960), dan "Plant Pathology" (Agrios, 1997). Identifikasi jamur patogen dilakukan hingga tingkat genus.

\section{HASIL DAN PEMBAHASAN}

Keragaman jamur patogen yang ditemukan dalam proses identifikasi dari gejala penyakit tanaman cabai merah di dataran rendah wilayah Kelurahan Padang Serai Kota Bengkulu dan Desa Pekik Nyaring Kabupaten Bengkulu Tengah tersaji pada Tabel 1. 
Tabel 1. Keanekaragaman jamur patogen di dataran rendah wilayah Kelurahan Padang Serai dan Desa Pekik Nyaring

\begin{tabular}{llcc}
\hline Jamur Patogen & Penyakit & \multicolumn{2}{c}{ Lokasi Pengambilan Sampel } \\
\cline { 2 - 4 } Fusarium sp. & Layu Fusarium & $\sqrt{ }$ & Pekik Nyaring \\
Curvularia sp. & Busuk cokelat buah & $\sqrt{ }$ & - \\
Colletotrichum sp. & Antraknosa & - & $\sqrt{ }$ \\
Cercospora sp. & Bercak Cercospora & - & $\sqrt{ }$ \\
Phytophthora sp. & Busuk daun Phytophthora & - & $\sqrt{ }$ \\
\hline Jumlah jamur patogen di setiap lokasi pengambilan sampel & 2 & 4 \\
\hline Total jumlah jenis jamur patogen & & 5 \\
\hline
\end{tabular}

Keterangan: $(\sqrt{ })=$ ditemukan jamur patogen pada sampel dari wilayah tersebut

$(-)=$ tidak ditemukan jamur patogen pada sampel dari wilayah tersebut

\section{Fusarium sp.}

Tanaman yang terinfeksi jamur Fusarium sp. akan menunjukkan gejala layu dan mati (Gambar 1). Fusarium sp. merupakan jamur patogen yang menyebabkan tanaman cabai merah mengalami penyakit layu fusarium. Tanaman yang terinfeksi Fusarium sp. akan layu dan mati.

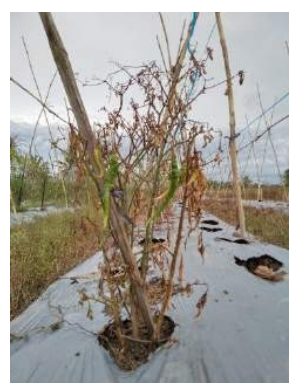

Gambar 1. Gejala tanaman yang terinfeksi Fusarium sp.

Fusarium sp. dapat menyebabkan kematian pada tanaman karena menjadi parasit bagi tanaman inangnya, terlebih Fusarium sp. tumbuh pada bagian pembuluh tanaman. Sehingga jaringan pembuluh tersumbat karena suatu toksin yang menyebabkan tanaman mati (Sastrahidayat, 2011).

Hasil pengamatan makroskopis jamur Fusarium sp. menunjukkan karakteristik makroskopis Fusarium sp., yakni memiliki koloni berwarna putih, teksturnya tebal dan halus seperti kapas, pertumbuhannya simetris. Secara mikroskopis, Fusarium sp. memiliki hifa hialin dan bersekat. Fusarium sp. bereproduksi dengan konidia. Fusarium sp. memiliki 2 jenis konidia, yakni mikrokonidia dan makrokonidia dengan warna hialin
(Gambar 2). Makrokonidia Fusarium sp. melengkung dan memiliki bentuk seperti bulan sabit yang meruncing pada setiap ujungnya, memiliki 3-6 sekat. Konidia Fusarium sp. memiliki panjang antara 16,2533,75 $\mu \mathrm{m}$ dan lebar antara 2,5-3,75 $\mu \mathrm{m}$.

Berdasarkan karakteristik makroskopis dan mikroskopis tersebut, diduga jamur yang ditemukan pada hasil isolasi tanaman cabai merah bergejala penyakit tersebut adalah jamur Fusarium sp. Dugaan ini didukung oleh pernyataan Barnett (1960), yang menyatakan dalam media pertumbuhannya, koloni Fusarium sp. berbentuk seperti kapas berwarna putih, dan seringkali terdapat warna merah jambu, ungu, ataupun kuning pada miseliumnya. Konidia hialin terdiri atas mikrokonidia dan makrokonidia. Makrokonidia terdiri atas beberapa sel, berbentuk melengkung dengan setiap ujung yang runcing. Mikrokonidia berbentuk bulat telur atau lonjong yang terdiri atas 1 sel. Ukuran makrokonidia Fusarium sp. antara 17-55 × 3,3-5,5 $\mu \mathrm{m}$. Makrokonidia memiliki 4-8 sekat dengan bentuk yang lurus atau sedikit bengkok. Mikrokonidia berukuran 16 $\times$ 2,4-3,5 $\mu \mathrm{m}$, memiliki 1-2 sekat dan berbentuk bulat atau menyerupai ginjal.

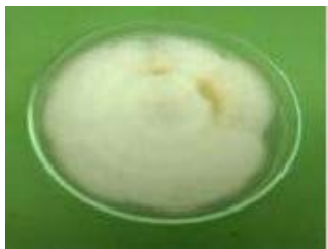

(a)

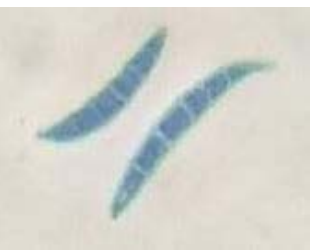

(b)
Gambar 2. (a) Koloni Fusarium sp. (b) konidia Fusarium sp. (diamati dengan mikroskop listrik, perbesaran $4 \times 10$ ) 


\section{Curvularia sp.}

Jamur Curvularia sp. diperoleh dari buah cabai merah yang berpenyakit. Gejalanya adalah terdapat luka seperti terbakar pada buah cabai merah, luka ini menyebabkan buah menjadi busuk (Gambar 3).

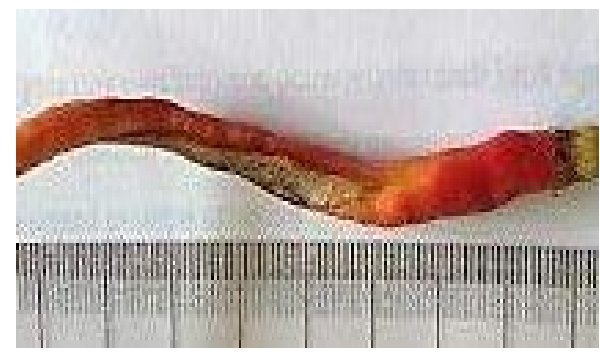

Gambar 3. Gejala buah cabai merah (C. annum L.) terinfeksi Culvularia sp.

Curvularia sp. merupakan jamur patogen tular-benih. Koloni berwarna abu-abu kehitaman, memilki permukaan yang halus tipis seperti kapas, arah pertumbuhan ke samping dan ke atas, bagian dasar berwarna hitam, membentuk zona cincin yang rapat dan bentuk koloni beraturan membentuk lingkaran. Berdasarkan ciri mikroskopisnya, hifa Curvularia sp. berwarna hialin dan bersekat. Konidia Curvularia sp. berbentuk seperti batang yang bengkok berwarna hialin dan kehitaman serta memiliki 3 sekat (Gambar 4). Ukuran konidia Curvularia sp. memilki panjang antara 18,75-26,25 $\mu \mathrm{m}$, dan memilki lebar antara 11,25-15 $\mu \mathrm{m}$. berdasarkan ciri maktoskopis dan mikroskopis tersebut, diduga jamur yang ditemukan pada hasil isolasi buah cabai merah yang bergejala penyakit tersebut adalah Curvularia sp.

Dugaan ini didukung oleh hasil penelitian Sobianti et. al. (2020), yang mendeskripsikan ciri makroskopis dan mikroskopis Curvularia sp., yakni koloni Curvularia sp. Berwarna kelabu kehitaman, dengan permukaan halus seperti kapas. Sedangkan karakteristik mikroskopis jamur ini adalah memiliki konidia berwarna pucat hingga kehitaman dengan bentuk sedikit melengkung. Konidia jamur ini memiiki 3 sekat, dengan sel ketiga memiliki ukuran yang lebih besar dan lebih gelap dari sel lainnya. Amtemea \& Tefa (2018), menjelaskan dalam hasil penelitiannya bahwa konidia Curvularia sp. memiliki ukuran antara 16-26 $\mu \mathrm{m} \times 8-12$ $\mu \mathrm{m}$ dan berwarna cokelat.

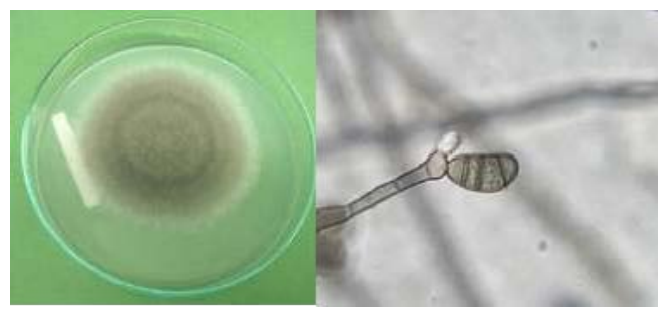

(a) (b)

Gambar 4. (a) Koloni Curvularia sp. (b) konidia Curvularia sp. (diamati dengan mikroskop listrik, perbesaran $4 \times 10$ )

\section{Colletotrichum sp.}

Gejala tanaman yang terinfeksi jamur Colletotrichum sp. memiliki ciri berupa bintik berwarna kehitaman pada buah cabai merah. Bintik tersebut akan melebar dan menyebabkan buah menjadi busuk. Gejala tersebut dinamakan dengan penyakit antraknosa/patek. Agrios (1997), menjelaskan penyakit pada batang, daun dan buah yang dapat diamati dengan adanya bintik berwarna gelap dan berbentuk cekung (Gambar 5).

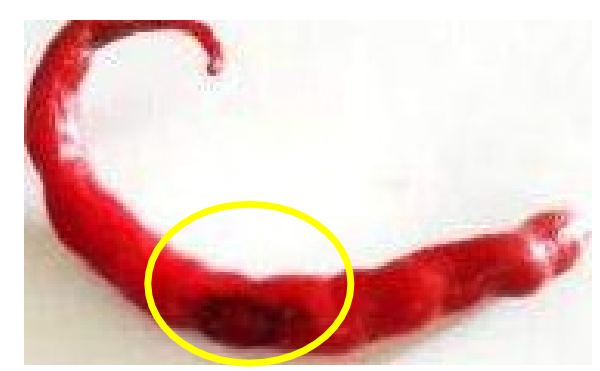

Gambar 5. Gejala infeksi Colletotrichum sp.

Secara makroskopis, jamur Colletotrichum sp. memiliki koloni berwarna abu-abu dengan tepi berwarna putih, permukaan halus dan rata, arah pertumbuhan ke samping menutupi media PDA, dan bentuk koloni beraturan. Dalam pengamatan mikroskopis, Colletotrichum sp. memilki hifa berwarna hialin, bercabang, dan bersekat, Konidia Colletotrichum sp. memanjang dengan ujung membulat, tidak bersekat dan berwarna hialin (Gambar 6). Panjang konidia Colletotrichum sp. Antara 5-10 $\mu \mathrm{m}$.

Hasil pengamatan yang diperoleh diduga bahwa jamur yang diperoleh dari gejala antraknosa adalah jamur 
Colletotrichum sp., dugaan ini didukung oleh pernyataan Barnett (1960), yang mendeskripsikan ciri mikroskopis Colletotrichum sp., yakni konidia bersel 1 dengan warna hialin dan berbentuk bulat telur atau lonjong. Data tersebut sesuai dengan hasil penelitian Dwiastuti \& Fajrin (2014). Yang menyatakan bahwa konidia berbentuk obovate, lurus dan panjangnya berkisar 38,743,9 $\mu \mathrm{m}$. data yang diperoleh pada hasil pengamatan secara mikroskopis, ukuran konidianya berbeda dengan data tersebut. Faktor yang mempengaruhi perbedaan tersebut salah satunya dissebabkan oleh perbedaan spesies ataupun media tumbuh jamurnya.

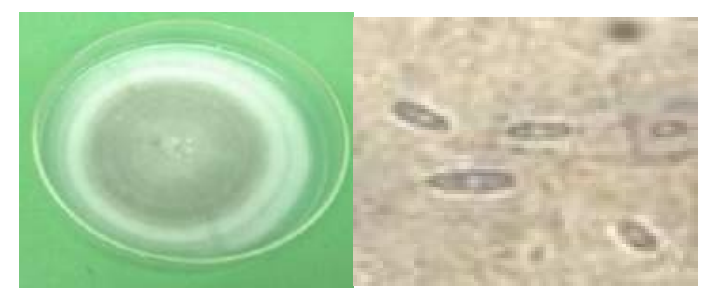

(a) (b)

Gambar 6. (a) Koloni Colletotrichum sp. (b) Konidia Colletotrichum sp. (diamati dengan mikroskop listrik, perbesaran $4 \times 10$ )

\section{Cercospora sp.}

Gejala yang ditimbulkan pada tanaman yang terinfeksi jamur Cercospora sp. adalah terdapat bintik berwarna cokelat pada daun tanaman cabai merah (Gambar 7).

Cercospora sp. dapat menyebabkan penyakit bercak daun pada cabai merah. Berdasarkan hasil pengamatan, konidia jamur Cercospora sp. berbentuk seperti tongkat, bersekat dengan panjang antara 27,5-90 $\mu \mathrm{m}$ dan lebar antara 2,5-3,75 $\mu \mathrm{m}$.

(a)

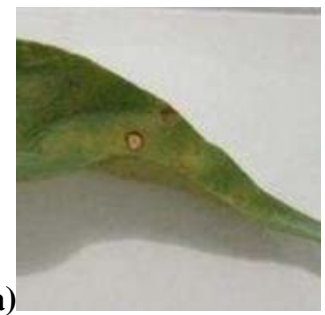

(b)

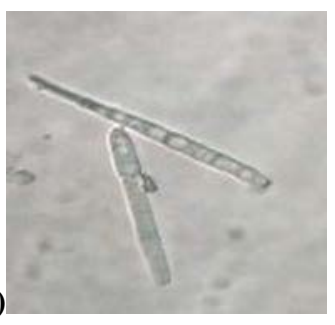

(c)

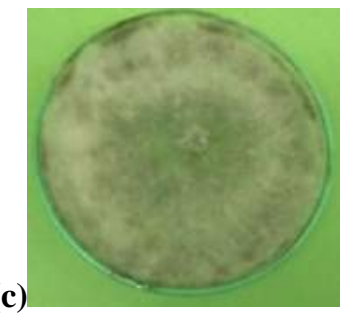

(d)

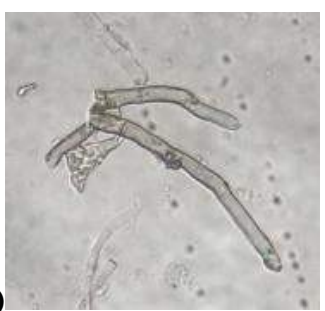

Gambar 7. (a) gejala daun cabai merah (C. annum L.) terinfeksi Cercospora sp.; (b) konidia Cercospora sp.; (c) koloni Cercospora sp.; (d) konidiofor Cercospora sp. (diamati dengan mikroskop listrik, perbesaran $4 \times 10$ )

Jamur Cercospora sp. Memiliki konidiofor berwarna gelap. Konidia berwarna gelap, memilki 3 sekat atau lebih. Bersifat parasit ataupun saprofit (Barnett, 1960).

\section{Phytophtora sp.}

Gejala yang ditimbulkan oleh infeksi jamur phytophtora sp. Pada tanaman adalah ujung cabai merah membusuk hingga menyebabkan daun rontok (Gambar 8).

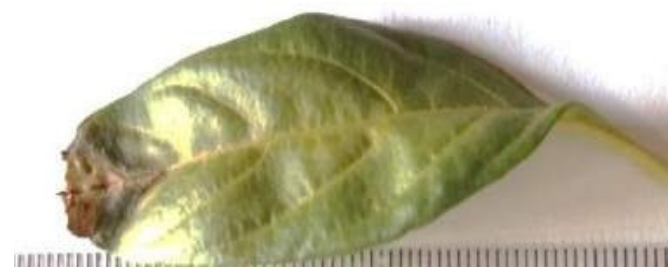

Gambar 8. Gejala daun cabai merah (C. annuum L.) terinfeksi Phytophthora sp.

Jamur Phytophthora sp. merupakan jamur patogen yang secara makroskopis memiliki koloni berwarna putih, permukaan halus dan rata seperti kapas. Arah pertumbuhan miselium ke samping dan keatas. Bentuk koloni beraturan membentuk lingkaran. Secara mikroskopis, Phytophtora sp. Memiliki spora berebentuk bulat telur berwarna cokelat dengan panjang antara 8,75$12,5 \mu \mathrm{m}$. ukuran konidia Phytophtora sp. Juga dipaparkan dalam hasil penelitian Ivayani (2018), yakni konidia Phytophthora sp. memiliki ukuran diameter rata-rata 14,2-19 $\mu \mathrm{m} \times 14,4-22,2 \mu \mathrm{m}$. Miselium menghasilkan sporangiofor bercabang yang menghasilkan sporangia berbentuk lemon pada ujung sporangiofor, pembengkakan miselium menjadi sporangiofor inilah yang menjadi ciri khas jamur Phytophhora sp. (Agrios, 1997). 


\section{PENUTUP}

Jamur patogen dan gejala penyakit yang diperoleh berdasarkan identifikasi yang telah dilakukan diantaranya adalah Fusarium sp. dengan gejala layu Fusarium, Curvularia sp. dengan gejala bercak cokelat buah, Colletotricum sp. dengan gejala antraknosa, Cercospora sp. dengan gejala bercak daun Cercospora, dan Phytophythora sp. dengan gejala busuk daun Phytophthora.

\section{DAFTAR PUSTAKA}

Agrios, G.N. (1997). Plant Pathology Fourth Edition. United States of America: Academic Press.

Amtemea, K., \& Tefab, A. (2018). Identifikasi Cendawan Patogen pada Beberapa Varietas Benih Padi Sawah Berdasarkan Model Penyimpanan. Jurnal Pertanian Konservasi Lahan Kering. 3(1): 4-7.

Barnett, H.L. (1960). Imperfect Fungi (2nd Ed.). West Virginia: Burgess Publishing Company.

Duriat, A.S., Gunaeni, N., \& Wulandari, A.W. (2007). Penyakit Penting Tanaman Cabai dan Pengendaliannya. Bandung: Balai Penelitian Tanaman Sayuran.

Dwiastuti, M.E., \& Melysa, N.F. (November, 2014). Penyakit Busuk Akar dan Mahkota Pada Stroberi (Fragaria x ananassa Dutch.) dan Agens Hayatinya. Naskah dipresentasikan pada Prosiding Seminar Nasional PERHORTI, Malang, Jawa Timur.

Ed-har , A.A., Widyastuti, R., \& Djajakirana, G. (2017). Isolasi dan Identifikasi Mikroba Tanah Pendegradasi Selulosa Dan Pektin Dari Rhizosfer Aquilaria malaccensis. Buletin Tanah dan Lahan. 1(1): 58-64.

Fahruddin, M.A., Fransiske, T., Risnanda, T. \& Irene, R.E. (2016). Efektivitas Antibakteri Ekstrak Buah Patikala (Etlingeraelatior (Jack) R.M. S.m) Terhadap Bakteri Enterococcus faecalis. Makassar Dent J . 5 (3): 69-75
Gandjar, I., \& Sjamsuridzal, W. (2006). Mikologi Dasar dan Terapan. Jakarta: Yayasan Obor Indonesia.

Harpenas, A., \& Dermawan, R. (2010). Budidaya Cabai Unggul. Jakarta: Penebar Swadaya.

Ivayani., Faishol, F., Sudihartha, N., \& Prasetyo, J. (2018). Efektivitas Beberapa Isolat Trichoderma Sp. Terhadap Keterjadian Penyakit Bulai yang Disebabkan oleh Peronosclerospora maydis dan Pertumbuhan Tanaman Jagung (Zea mays). Jurnal Penelitian Pertanian Terapan. 18(1): 39-45.

Sari,W., Wiyono, S., Nurmansyah, A., Munif, A., \& Poerwanto, R. (2017). Keanekaragaman dan Patogenisitas Fusarium spp. Asal Beberapa Kultivar Pisang. Jurnal Fitopatologi Indonesia. 13(6): 216-228.

Sastrahidayat, I. R. (2011). Fitopatologi (Ilmu Penyakit Tumbuhan). Jakarta: UB Press.

Subagyono, K. (2010). Budidaya dan Pascapanen Cabai Merah (Capsicum annum L.). Jawa Tengah: Badan Penelitian dan Pengembangan Pertanian Balai Pengkajian Teknologi Pertanian.

Sobianti, S., Soesanto, L., \& Hadi, S. 2020. Inventarisasi Jamur Patogen TularBenih pada Lima Varietas Padi. Agricultural Journal. 3(1): 1-15.

Tanjung, M.Y., Kristalisasi, E.N., \& Yuniasih, B. (2018). Keanekaragaman Hama dan Penyakit Pada Tanaman Cabai Merah (Capsicum annum L) Pada Daerah Pesisir dan Dataran Rendah. Jurnal Agromast. 3(1): 1-10.

Wulandari, D., Sulistyowati, L., \& Muhibuddin, A. (2014). Keanekaragaman Jamur Endofit Pada Tanaman Tomat (Lycopersicum esculentum Mill.) dan Kemampuan Antagonisnya Terhadap Phytophthora infestans. Jurnal HPT. 2(1): 110-118. 